\title{
IMPLEMENTASI SLIP GAJI ELEKTRONIK PADA CV MEDIAKU KREATIF (MOTION PRODUCTION)
}

\author{
Yesni Malau ${ }^{1}$, Tubagus Aom Somadiningrat D.W.K ${ }^{2}$ \\ ${ }^{1}$ Program Studi Manajemen Administrasi \\ Akademi Sekretari dan Manajemen Bina Sarana Informatika \\ ASM BSI JAKARTA \\ Email: yesni.ymu@bsi.ac.id \\ ${ }^{2}$ Program Studi Sistem Informasi \\ Sekolah Tinggi Manajemen Informatika dan Komputer Nusa Mandiri \\ STMIK Nusa Mandiri Jakarta \\ Email: Tubagus.aom.swk@gmail.com
}

\begin{abstract}
Abstrak
Sistem penggajian yang telah terkomputerisasi dapat membantu CV Mediaku Kreatif (Motion Production) dalam mengolah data penggajian karyawannya, waktu yang dibutuhkan lebih cepat, tepat dan akurat, backup data lebih terstruktur dan terorganisir sehingga memudahkan pada saat proses pencarian data, dengan adanya Implementasi slip gaji elektronik akan memudahkan bagi karyawan yang sedang tugas diluar untuk dapat menerima slip gaji tanpa harus berada di kantor karena karyawan dapat melihat slip gaji melalui email yang dapat diakses dimanapun. Selain memudahkan proses penggajian, implementasi slip gaji elektronik pada CV Mediaku Kreatif (Motion Production) dapat menghemat biaya karena slip gaji elektronik menggunakan sistem paperless. Pembangunan sistem slip gaji elektronik pada CV Mediaku Kreatif (Motion Production) dimulai dari proses analisis kebutuhan sistem, dilanjutkan dengan proses desain dan pembuatan sistem yang didasarkan dari hasil analisis kebutuhan, tahap terakhir adalah pengujian dan implementasi sistem menjadi sebuah sistem yang menghasilkan sebuah sistem slip gaji elektronik pada CV Mediaku Kreatif (Motion Production).
\end{abstract}

Kata kunci : penggajian, slip gaji elektronik

\begin{abstract}
Computerized payroll systems can help CV Mediaku Kreatif (Motion Production) in processing data payroll employees, the time required faster, precise and accurate, data backups more structured and organized so as to facilitate the process of searching data, with the implementation of electronic salary slip will make it easier for employees who are on duty outside to be able to receive a paycheck without having to be in the office because employees can see the paycheck via email that can be accessed anywhere. In addition to facilitating the payroll process, the implementation of electronic salary slip on CV Mediaku Kreatif (Motion Production) can save costs due to electronic salary slip using paperless system. Development of electronic salary slip system on CV Mediaku Kreatif (Motion Production) starts from the process of system requirement analysis, followed by the process of design and manufacture of systems based on the results of needs analysis, the last stage is testing and implementation of the system into a system that generates a paycheck system electronics on CV Mediaku Kreatif (Motion Production).
\end{abstract}

Keyword : electronic payment slip, payroll 


\section{Pendahuluan}

Proses pengolahan data untuk penggajian pada $\mathrm{CV}$. Media Ku Kreatif (Motion Production) masih menggunakan Microsoft Office sehingga pada saat pengolahan data gaji sering kali menemukan beberapa permasalahan diantaranya kerangkapan data, dokumen rusak atau dokumen hilang dan kesalahan perhitungan data, belum lagi permasalahan kebutuhan waktu yang dibutuhkan dalam melakukan pengolahan data untuk menghasilkan slip gaji dan laporan penggajian. Berdasarkan permasalahan yang telah diuraikan tersebut maka dibutuhkan sebuah sistem penggajian terkomputerisasi yang dapat menjadi solusi akan permasalahan yang ada.

$\begin{array}{ccr}\text { Dengan } & \text { membangun } & \text { sistem } \\ \text { penggajian } & \text { terkomputerisasi } & \text { akan }\end{array}$ memudahkan CV Mediaku Kreatif (Motion Production) dalam perhitungan data untuk menghasilkan slip gaji dan laporan penggajian karena waktu yang dibutuhkan dalam pengolahan data akan lebih cepat dengan hasil perhitungan tepat dan akurat. Demikian pula untuk kendala pada saat proses pencarian dokumen, dengan sistem penyimpanan data dan backup data yang terstruktur dan terorganisir akan memudahkan dalam proses pencarian data yang dibutuhkan.

Dengan diterapkannya implementasi slip gaji elektronik pada CV Mediaku Kreatif (Motion Production) akan memudahkan karyawan untuk melihat slip gaji tanpa harus berada dikantor, karena karyawan dapat mengakses email dimanapun berada, hal ini akan memudahkan karyawan yang ingin melihat rincian gaji walau sedang berada keluar kota, Dan untuk CV Mediaku Kreatif (Motion Production) akan menghemat biaya karena slip gaji elektronik menggunakan sistem paperless.

\section{a. Sistem Penggajian}

Menurut (Mardi, 2011 ) sistem penggajian merupakan salah satu aplikasi pada sistem informasi akuntansi yang terus mengalami proses dalam bentuk batch (bertahap).

Menurut (Mardi, 2011 ) Sistem penggajian terkomputerisasi adalah sistem pengolahan gaji yang dilakukan dengan bantuan fasilitas perangkat lunak atau program yang telah didesain untuk keperluan pengelolaan sistem penggajian dan upah di perusahaan.

b. Pemrograman Berorientasi Objek

Menurut(Rosa \& Shalahuddin, 2015) Metodologi berorientasi objek adalah suatu strategi pembangunan perangkat lunak yang mengorganisasikan perangkat lunak sebagai kumpulan objek yang berisi data dan operasi yang diberlakukan terhadapnya dan metodologi berorientasi objek merupakan suatu cara bagaimana sistem perangkat lunak dibangun melalui pendekatan objek secara sistematis.

c. Unified Modeling Language (UML)

Menurut (Rosa \& Shalahuddin, 2015) UML (Unified Modeling Language) adalah salah standar bahasa yang banyak digunakan di dunia industri untuk mendefinisikan requirement, membuat analisis dan desain, serta menggambarkan arsitektur dalam pemrograman berorientasi objek. UML merupakan bahasa visual untuk pemodelan dan komunikasi mengenai sebuah sistem dengan menggunakan diagram dan teks-teks pendukung.

Berikut adalah penjelasan masingmasing diagram yang mendukung dalam penyusunan skripsi:

a) Class Diagram

Diagram kelas atau Class diagram menggambarkan struktur sistem dari segi pendefinisian kelas-kelas yang akan dibuat untuk membangun sistem.

b) Component Diagram

Diagram komponen atau component diagram dibuat untuk menunjukkan organisasi dan ketergantungan diantara kumpulan komponen dalam sebuah sistem.

c) Deployment Diagram

Diagram deployment atau deployment diagram menunjukan konfigurasi komponen dalam proses eksekusi aplikasi.

d) Use Case Diagram

Use case mendeskripsikan sebuah interaksi antara satu atau lebih aktor dengan sistem informasi yang akan dibuat.

e) Activity Diagram

Diagram aktivitas atau activity diagram menggambarkan workflow (aliran kerja) atau aktivitas dari sebuah sistem atau 
proses bisnis atau menu yang ada pada perangkat lunak.

f) Sequence Diagram

Diagram sekuen menggambarkan kelakuan objek pada use case dengan mendeskripsikan waktu hidup objek dan message yang dikirimkan dan diterima antar objek.

\section{d. Entity Relationship Diagram (ERD)}

Menurut (Yaqub, 2008) Entity Relationship Diagram merupakan suatu model jaringan yang menggunakan susunan data yang disimpan pada sistem secara abstrak. Entity Relationship Diagram juga menggambarkan hubungan antara satu entitas yang memiliki sejumlah atribut dengan entitas yang lain dalam suatu sistem yang terintegrasi. Dalam Entity Relationship Diagram juga dikenal dengan derajat relasai atau kardinalitas yaitu menunjukkan maksimum entitas yang dapat be-relasi dengan entitas pada himpunan entitas, dapat berupa satu ke satu (one-to-one), satu ke banyak (one-to-many), dan banyak ke banyak (many-to-many)

e. Logical Record Structure (LRS)

Menurut (Kusrini, 2007), Logical Record Structure adalah representasi dari struktur record-record pada tabel-tabel yang terbentuk dari hasil antar himpunan entitas, menentukan kardinalitas, jumlah table dan Foreign Key (FK).

\section{f. Structured Query Language (SQL)}

Menurut (Raharjo, 2011) Structured Query Language (SQL) yaitu kependekan dari Structured Query Language yang merupakan bahasa atau kumpulan perintah standar yang digunakan untuk berkomunikasi dengan database.

g. PHP Hypertext Preprocessor

Menurut (Kadir, 2008) PHP Hypertext Preprocessor merupakan bahasa pemrograman skrip yang diletakan dalam server yang biasa digunakan untuk membuat aplikasi WEB yang bersifat dinamis.

\section{h. Hypertext Markup Language (HTML)}

Menurut (Suyanto \& Asep, 2009) Hypertext Markup Language (HTML) merupakan bahasa yang digunakan untuk menulis halaman web. Biasanya mempunya ekstensi .htm, .html, atau shtml. Html tersusun atas tag-tag, digunakan untuk menentukan tampilan dari dokumen HTML, yang diterjemahkan oleh browser.

\section{i. Black-box Testing}

Menurut (Rosa \& Shalahuddin, 2015) Black-Box Testing (pengujian kotak hitam) adalah menguji perangkat lunak dari segi spesifikasi fungsional tanpa menguji desain dan kode program. Pengujian dilakukan dengan membuat kasus uji yang bersifat mencoba semua fungsi dengan memakai perangkat lunak apakah sesuai dengan spesifikasi yang dibutuhkan.

Untuk mendapatkan data yang diperlukan dalam membangun sistem penggajian yang terkomputerisasi dengan sistem implementasi slip gaji elektronik pada CV Mediaku Kreatif (Motion Production) metode penelitian yang digunakan antara lain:

\section{Metode Penelitian}

\subsection{Teknik Pengumpulan Data}

Teknik pengumpulan data yang digunakan adalah:

\section{Observasi}

Pengamatan secara langsung terhadap proses penggajian pada CV. Mediaku Kreatif (Motion Production) dan mengumpulkan semua data yang dibutuhkan

\section{Wawancara}

Wawancara dilakukan untuk melengkapi data yang dibutuhkan dengan cara bertanya secara langsung

\section{Studi Pustaka}

Studi Pustaka dilakukan untuk menunjang metode observasi dan wawancara yang telah dilakukan. Studi pustaka dilakukan dengan menggunakan beberapa buku dan karya ilmiah sebagai referensi

\subsection{Model Pengembangan Sistem}

Model pengembangan sistem yang digunakan adalah model Waterfall atau sering juga disebut air terjun, dengan teknik pengumpulan data sebagai berikut: 
1. Analisa Kebutuhan Perangkat Lunak

Analisa kebutuhan perangkat lunak merupakan tahap awal yang dilakukan dalam merancang sistem. Menemukan permasalahan yang ada dengan cara mengumpulkan data (data fisik, non fisik) melalui observasi, wawancara dan studi pustaka.

2. Desain

Desain yang dimaksud bukan hanya tampilan atau interfacenya saja, tetapi yang dimaksud desain dalam metode ini adalah desain sistem yang meliputi: alur kerja sistem, cara pengoprasian sistem, hasil keluaran (output) dengan menggunakan UML (Unified Modeling Language) tampilan sistem dan rancangan database yang telah disesuaikan dengan analisis kebutuhan pada tahap awal untuk menyelesaikan permasalahan tersebut.

3. Pembuatan Kode Program

Pada tahap ini hasil dari fase-fase sebelumnya dituangkan kedalam penulisan kode-kode dengan menggunakan bahasa pemrograman yang dapat dimengerti oleh komputer. Hasil dari design atau perancangan mulai diterjemahkan ke dalam bahasa mesin menggunakan bahasa pemrograman salah satunya yaitu bahasa PHP, sedangkan untuk software programming menggunakan XAMPP sebagai server lokal dan text editor ATOM untuk pengodean program.

\section{Pengujian}

Pengujian merupakan tahap uji coba dari jaminan perangkat lunak dan mempresentasikan apakah sistem sudah benar dan sesuai kebutuhan sehingga akan dapat diketahui seperti apa hasil kinerja sistem yang baru ini dibandingkan dengan sistem yang lama, kemudian dapat diketahui pula apakah dalam sistem yang baru ini masih ada kelemahan yang kemudian dapat diperbaiki dan dikembangkan.

5. Pendukung (support) atau pemeliharaan (maintenance)

Pada tahap ini, merupakan tahap pemeliharaan atau maintenance terhadap aplikasi yang ada.

\section{Hasil dan Pembahasan}

\subsection{Analisa Kebutuhan Software}

Tahap Analisa kebutuhan adalah langkah awal dalam menentukan perangkat lunak yang akan dihasilkan.

\subsubsection{Tahap Analisa}

Terdapat lima pengguna yang dapat berinteraksi dengan lingkungan sistem penggajian yang akan dibangun yaitu administrator, owner, manager, administrasi dan karyawan. Berikut analisa kebutuhan berdasarkan kebutuhan pengguna terhadap sistem aplikasi peggajian karyawan:

A. Halaman Administrator

A.1. Administrator harus melakukan login

A.2. Administrator dapat mengelola data user

A.3. Administrator dapat melihat profil pribadi

A.4. Administrator dapat melihat data absensi pribadi

A.5. Administrator dapat melihat data gaji pribadi

A.6. Administrator dapat merubah password pribadi

B. Halaman Owner (Pemilik Perusahaan)

B.1. Owner harus melakukan login

B.2. Owner dapat melihat data jabatan

B.3. Owner dapat melihat data kegiatan

B.4. Owner dapat melihat data karyawan

B.5. Owner dapat melihat data absensi

B.6. Owner dapat melihat data penggajian

B.7. Owner dapat melihat profil pribadi

B.8. Owner dapat merubah password pribadi

C. Halaman Manager

C.1. Manager harus melakukan login

C.2. Manager dapat mengelola data jabatan

C.3. Manager dapat mengelola data kegiatan

C.4. Manager dapat melihat data karyawan

C.5. Manager dapat melihat data penggajian

C.6. Manager dapat melihat profil pribadi

C.7. Manager dapat melihat absensi pribadi 
C.8. Manager dapat melihat gaji pribadi

C.9. Manager dapat merubah password pribadi

D. Halaman Administrasi

D.1. Administrasi harus melakukan login

D.2. Administrasi dapat mengelola data karyawan

D.3. Administrasi dapat mengelola data absensi

D.4. Administrasi dapat mengelola data penggajian

D.5. Administrasi dapat melihat profil pribadi

D.6. Administrasi dapat melihat absensi pribadi

D.7. Administrasi dapat melihat gaji pribadi

D.8. Administrasi dapat merubah password pribadi

E. Halaman Karyawan

E.1. Karyawan harus melakukan login

E.2. Karyawan dapat melihat profil pribadi

E.3. Karyawan dapat melihat data absensi pribadi

E.4. Karyawan dapat melihat data slip gaji pribadi

E.5. Karyawan dapat merubah password pribadi

\subsubsection{Use Case Diagram}

A. Use Case Diagram Halaman Administrasi

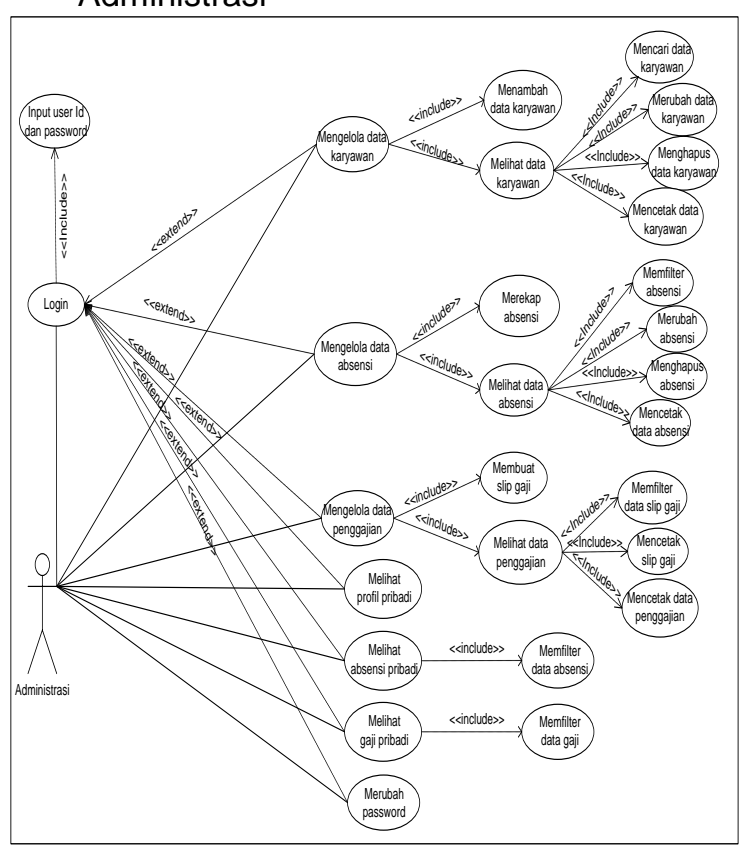

Gambar 1. Use Case Diagram Halaman Administrasi

B. Use Case Diagram Halaman Karyawan

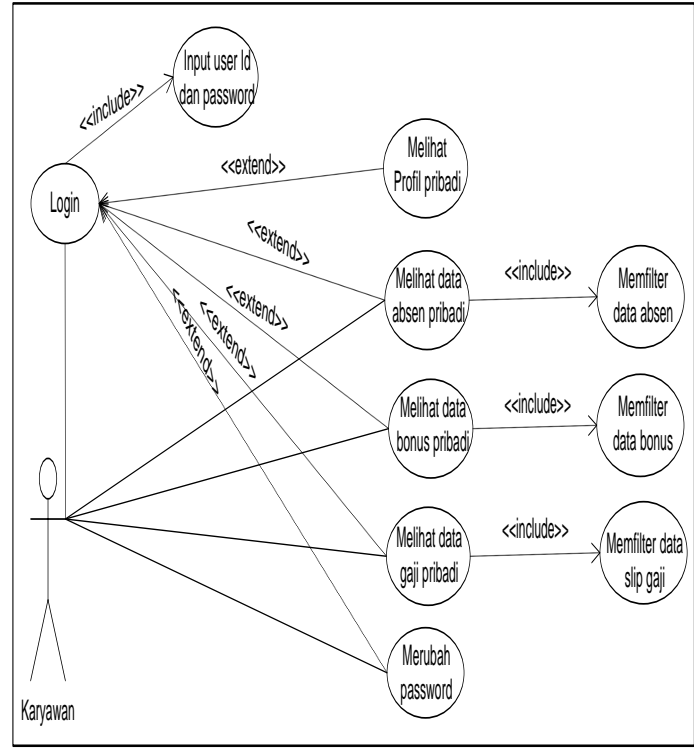

Gambar 2. Use Case Diagram Halaman Karyawan

\subsubsection{Activity Diagram}

Berikut ini adalah penggambaran rancangan diagram dari hasil analisa yang didapat:

A. Activity Diagram Administrasi

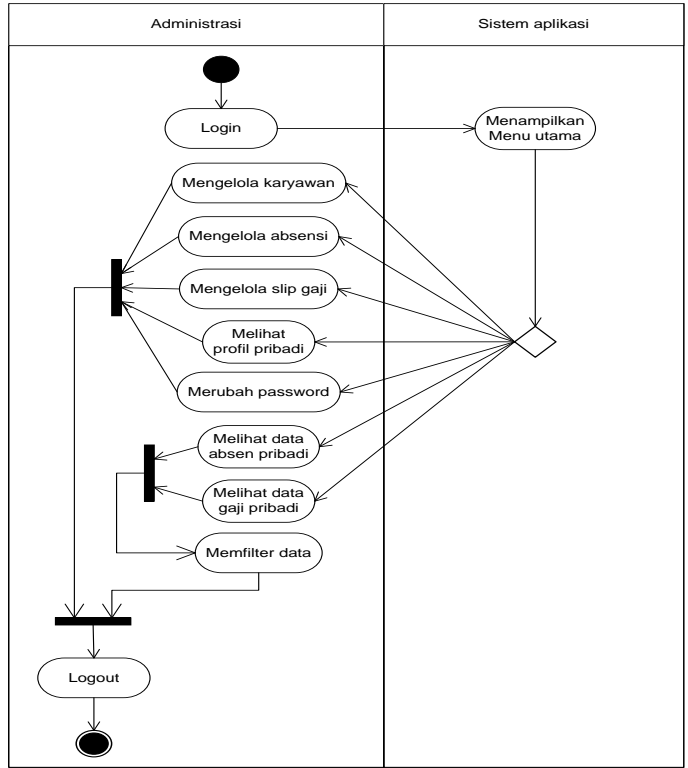

Gambar 3. Activity Diagram Administrasi 
B. Activity Diagram Karyawan

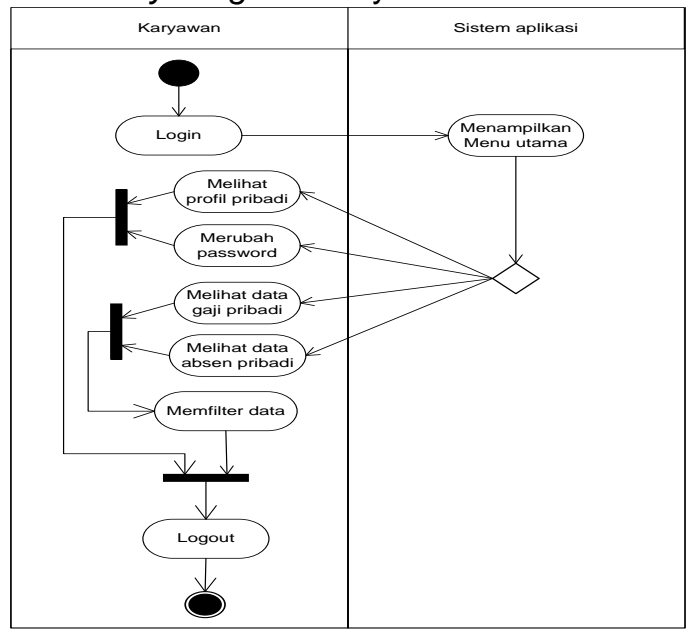

Gambar 4. Activity Diagram Karyawan

\subsection{Desain}

Pada tahap ini akan dirancang desain database, desain software architecture dan user Intrerface dari sistem penggajian dengan implementasi slip gaji elektronik pada CV Mediaku Kreatif (Motion Production)

\subsubsection{Database}

Membuat rancangan dengan menggunakan Entity Relationship Diagram (ERD), Logical Record Structure (LRS) dan spesifikasi file. Berikut ini adalah penggambaran rancangan menggunakan Entity Relationship Diagram (ERD), Logical Record Structure (LRS) beserta spesifikasi file untuk struktur sistem penggajian karyawan:

\section{A. Entity Relationship Diagram}

\section{Rancangan menggunakan Entity Relationship Diagram (ERD)}

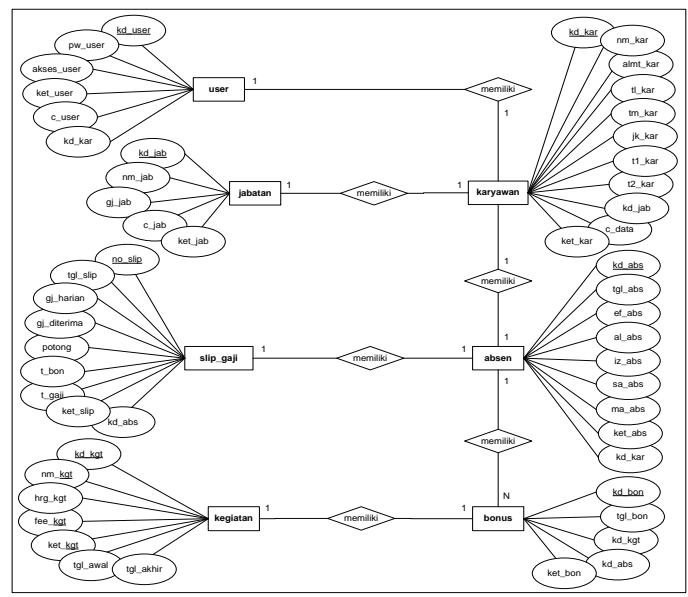

Gambar 5. Entity Relationship Diagram
B. Logical Record Structure Rancangan menggunakan Logical Record Structure (LRS)

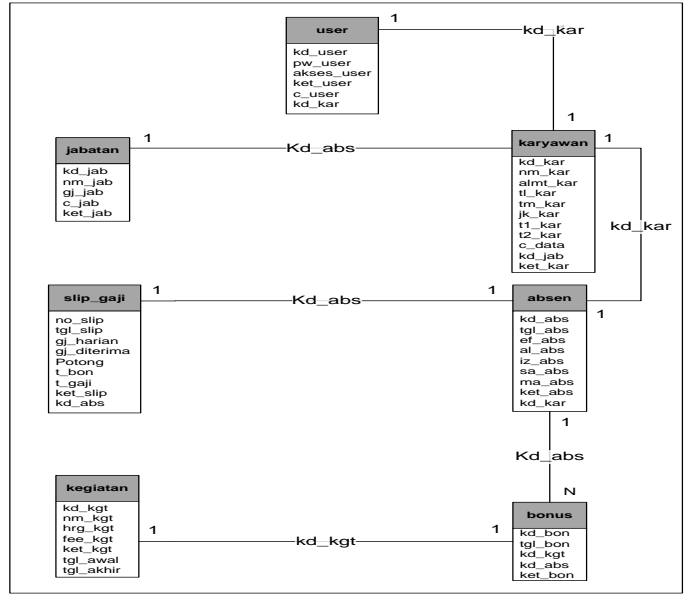

Gambar 6. Logical Record Structure

\subsubsection{Software Architecture}

A. Class Diagram

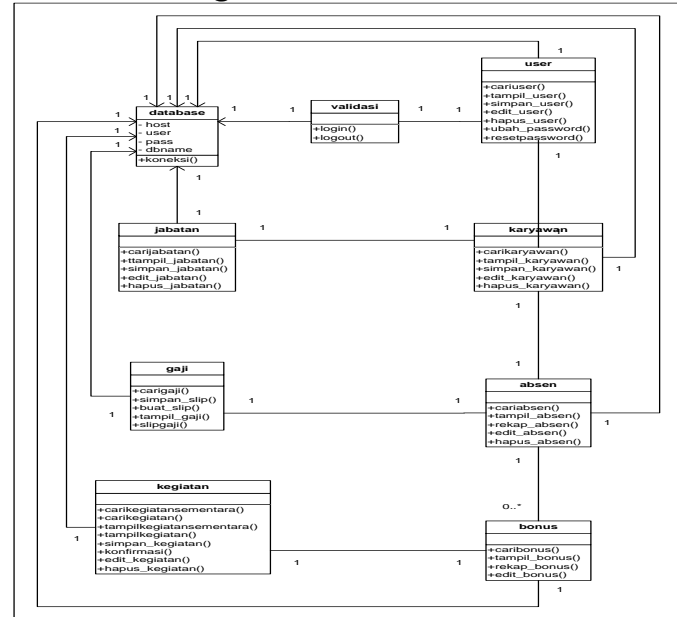

Gambar 7. Class Diagram sistem informasi penggajian karyawan

\section{B. Sequence Diagram}

1. Sequence Diagram Login

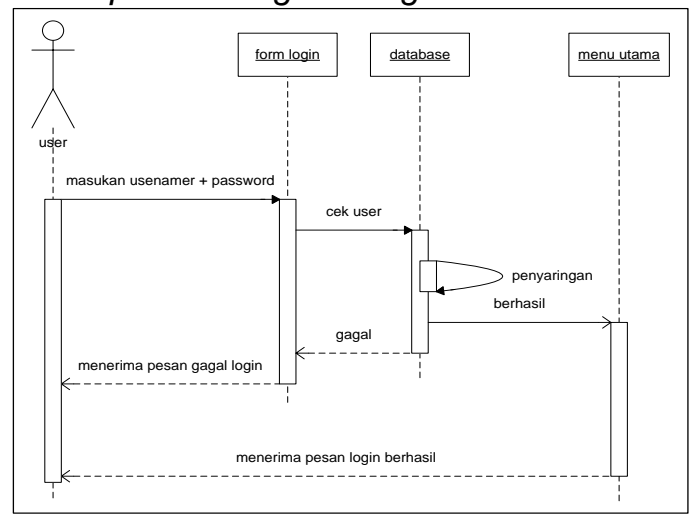

Gambar 8. Sequence diagram login 
2. Sequence Diagram Kelola Data User

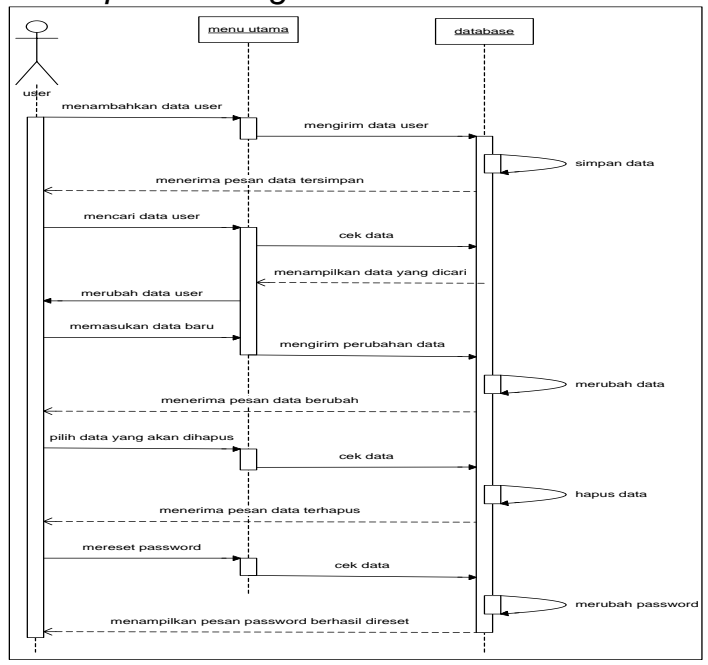

Gambar 9. Sequence diagram kelola data user

3. Sequence Diagram Kelola Data

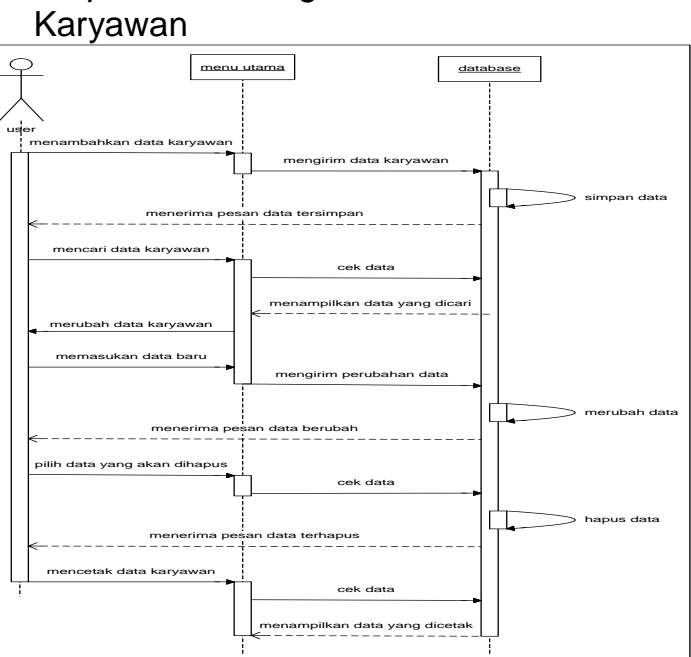

Gambar 10. Sequence diagram kelola data karyawan

4. Sequence Diagram Kelola Data Absensi

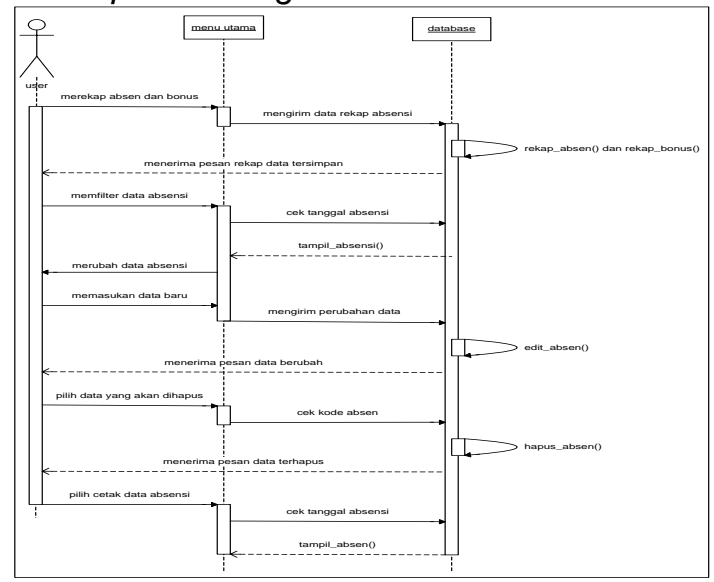

Gambar 11. Sequence diagram kelola data absensi
5. Sequence Diagram Kelola Data Penggajian

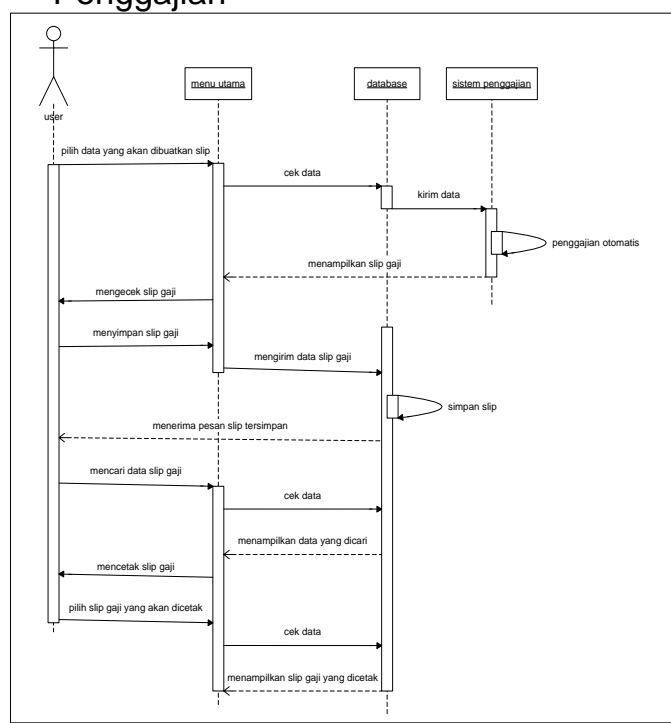

Gambar 12. Sequence diagram kelola data penggajian

\section{Component Diagram}

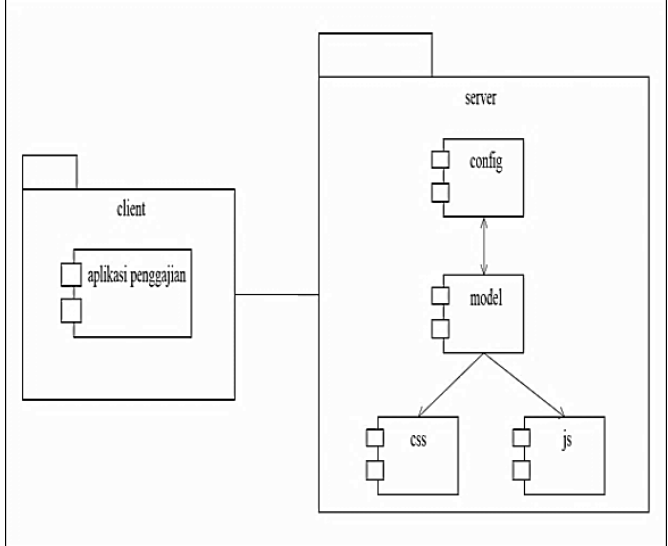

Gambar 13. Component Diagram

\section{Deployment Diagram}

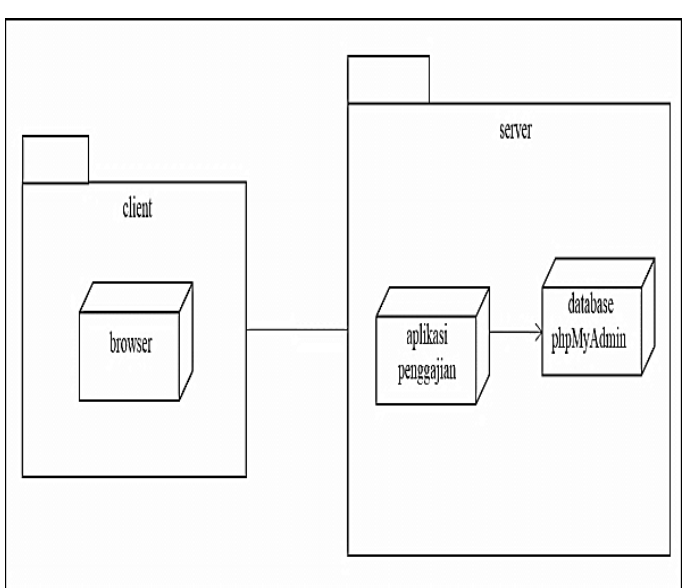

Gambar 14. Deployment Diagram 
3.3. User Interface

1. Tampilan Halaman Login

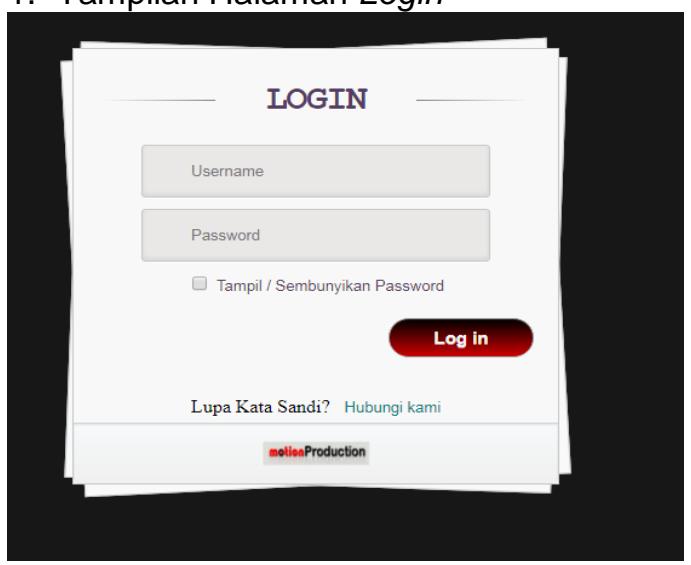

Gambar 15. Tampilan halaman login

2. Tampilan Halaman Data User

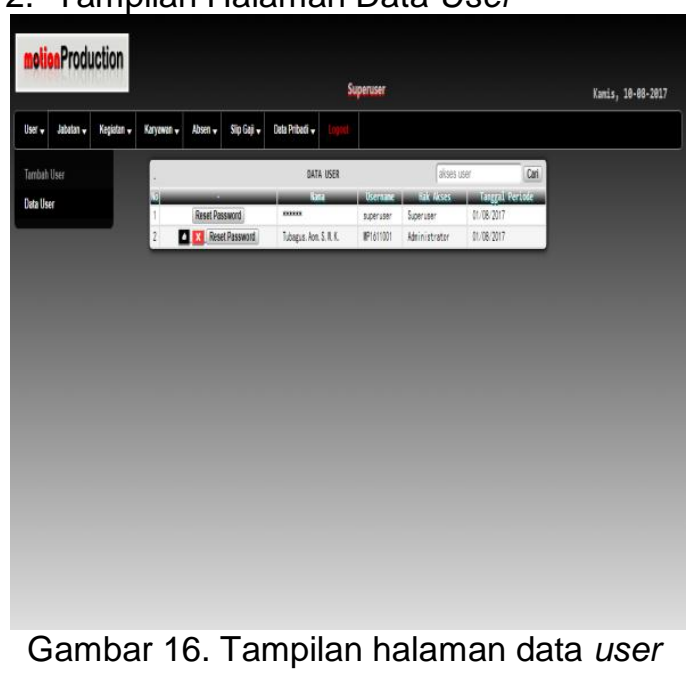

3. Tampilan Halaman Data Jabatan

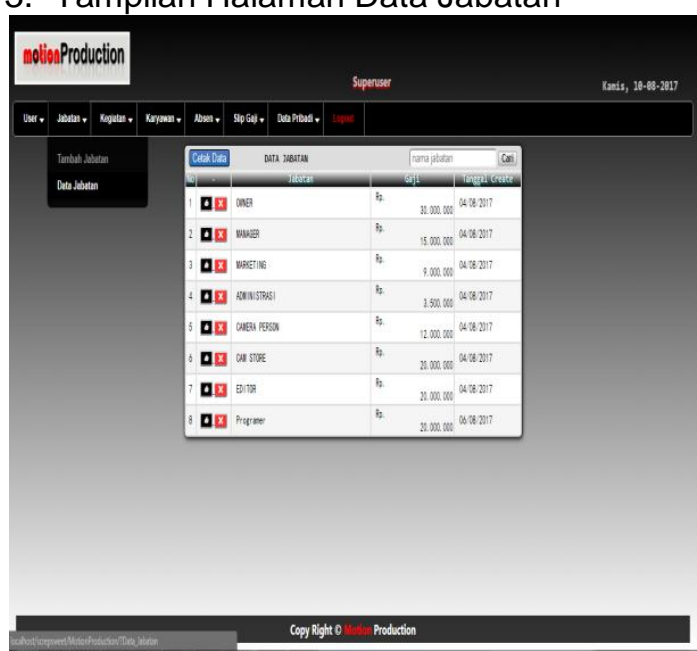

Gambar 17. Tampilan halaman data jabatan
4. Tampilan Halaman Data Karyawan

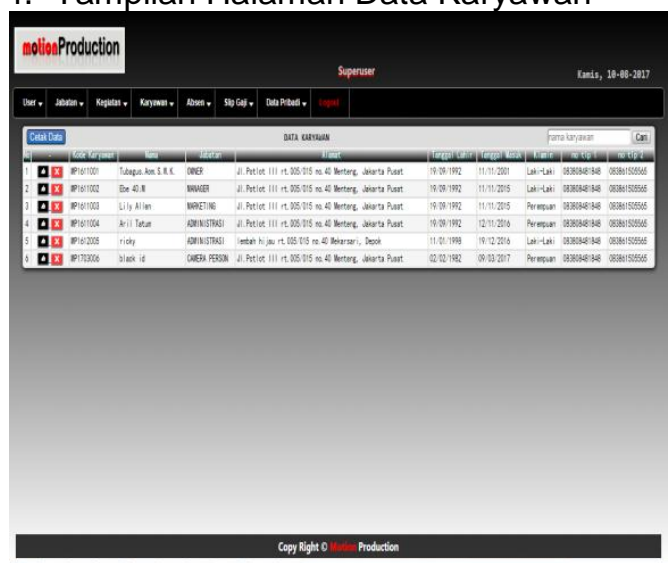

Gambar 18. Tampilan halaman data karyawan

5. Tampilan Halaman Data Absensi

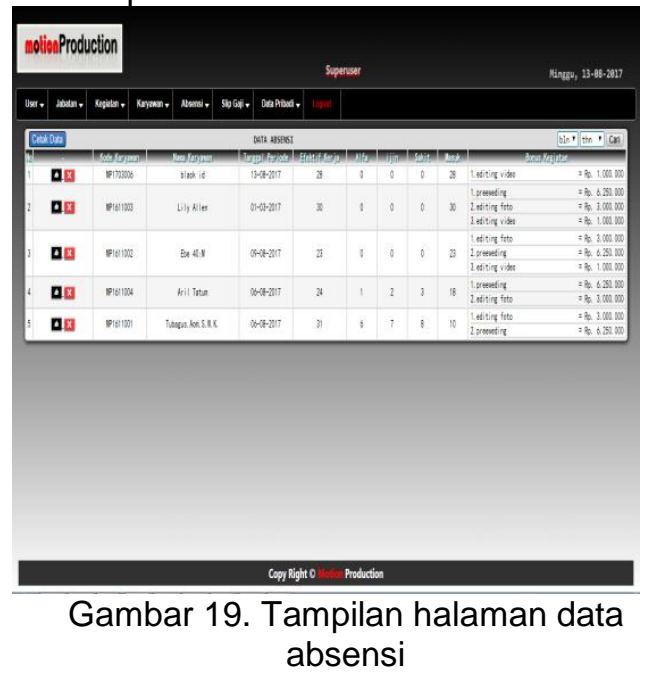

6. Tampilan halaman Perhitungan Gaji

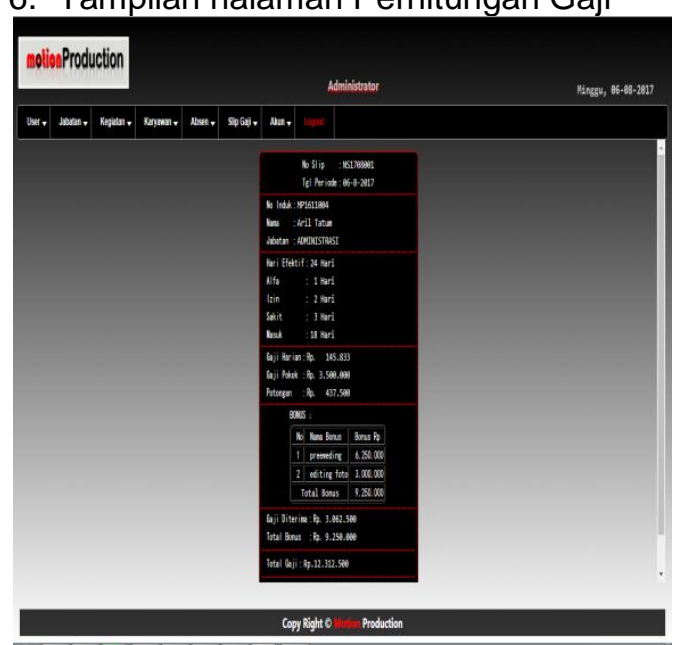

Gambar 20. Tampilan halaman perhitungan gaji 
7. Tampilan Halaman Data Slip Gaji

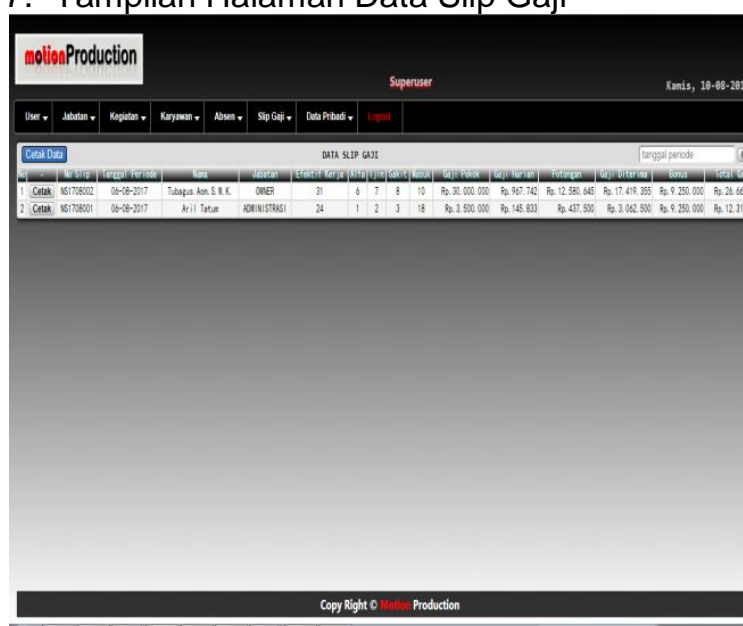

Gambar 21. Tampilan halaman data slip gaji

\section{Tampilan Slip Gaji Kirim ke email}

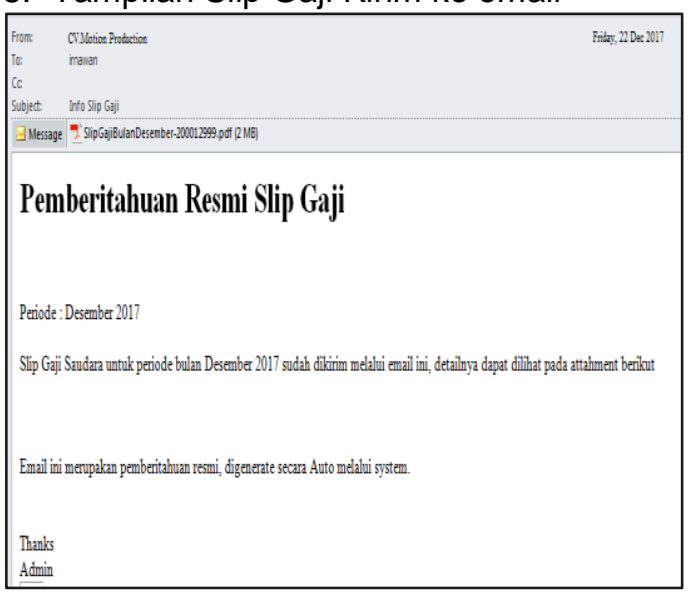

Gambar 22. Tampilan Slip Gaji Kirim ke email

\subsection{Testing}

A. Form Login

Table 1.

Hasil pengujian Black Box Testing Form

Login

\begin{tabular}{|c|l|l|l|l|l|}
\hline No & \multicolumn{1}{|c|}{$\begin{array}{c}\text { Skenario } \\
\text { Pengujian }\end{array}$} & Test Case & $\begin{array}{l}\text { Hasil yang } \\
\text { diharapkan }\end{array}$ & $\begin{array}{l}\text { Hasil } \\
\text { Pengujian }\end{array}$ & Kesimpulan \\
\hline 1 & $\begin{array}{l}\text { Mengosongkan } \\
\text { semua textbox } \\
\text { kemudian } \\
\text { menekan tombol } \\
\text { login }\end{array}$ & $\begin{array}{l}\text { User: } \\
\text { kosong } \\
\text { Password: } \\
\text { kosong }\end{array}$ & $\begin{array}{l}\text { Sistem } \\
\text { menolak dan } \\
\text { menampilkan } \\
\text { validasi } \\
\text { masukan } \\
\text { usermame }\end{array}$ & $\begin{array}{l}\text { Sesuai } \\
\text { harapan }\end{array}$ & Valid \\
\hline 2 & $\begin{array}{l}\text { Mengosongkan } \\
\text { textbox username } \\
\text { kemudian } \\
\text { menekan tombol } \\
\text { login }\end{array}$ & $\begin{array}{l}\text { User: } \\
\text { kosong } \\
\text { Password: } \\
\text { administrator }\end{array}$ & $\begin{array}{l}\text { Sistem } \\
\text { menolak dan } \\
\text { menampilkan } \\
\text { validasi } \\
\text { masukan } \\
\text { usemame }\end{array}$ & $\begin{array}{l}\text { Sesuai } \\
\text { harapan }\end{array}$ & Valid \\
\hline 3 & $\begin{array}{l}\text { Mengosongkan } \\
\text { textbox password } \\
\text { kemudian }\end{array}$ & $\begin{array}{l}\text { User: } \\
\text { NK1611001 } \\
\text { Password: } \\
\text { kosong }\end{array}$ & $\begin{array}{l}\text { Sistem } \\
\text { menolak dan } \\
\text { menampilkan } \\
\text { validasi } \\
\text { masukan } \\
\text { password }\end{array}$ & $\begin{array}{l}\text { Sesuai } \\
\text { harapan }\end{array}$ & Valid \\
\hline 4 & $\begin{array}{l}\text { Mengisi semua } \\
\text { textbox kemudian } \\
\text { menekan tombol } \\
\text { login }\end{array}$ & $\begin{array}{l}\text { User: } \\
\text { NK1611001 } \\
\text { Passord: } \\
\text { administrator }\end{array}$ & $\begin{array}{l}\text { Sistem } \\
\text { menerima } \\
\text { dialihkan ke } \\
\text { menu utama } \\
\text { sesuai hak } \\
\text { akses }\end{array}$ & $\begin{array}{l}\text { Sesuai } \\
\text { harapan }\end{array}$ & Valid \\
\hline
\end{tabular}

B. Form User

Table 2

Hasil pengujian Black Box Testing Form User

\begin{tabular}{|c|l|l|l|l|l|}
\hline No & Skenario Pengujian & \multicolumn{1}{|c|}{ Test Case } & $\begin{array}{l}\text { Hasil yang } \\
\text { diharapkan }\end{array}$ & $\begin{array}{c}\text { Hasil } \\
\text { Pengujian }\end{array}$ & Kesimpulan \\
\hline 1 & $\begin{array}{l}\text { Mengosongkan } \\
\text { semua selectbox } \\
\text { kemudian menekan } \\
\text { tombol simpan }\end{array}$ & $\begin{array}{l}\text { User: } \text { kosong } \\
\text { Hak akses: } \\
\text { kosong }\end{array}$ & $\begin{array}{l}\text { Sistem menolak } \\
\text { dan } \\
\text { menampilkan } \\
\text { validasi pilih } \\
\text { user }\end{array}$ & $\begin{array}{l}\text { Sesuai } \\
\text { harapan }\end{array}$ & Valid \\
\hline 2 & $\begin{array}{l}\text { Mengosongkan } \\
\text { selectbox user } \\
\text { kemudian menekan } \\
\text { tombol simpan }\end{array}$ & $\begin{array}{l}\text { User: } \text { kosong } \\
\text { Hak akses: } \\
\text { administrator }\end{array}$ & $\begin{array}{l}\text { Sistem menolak } \\
\text { dan } \\
\text { menampilkan } \\
\text { validasi pilih } \\
\text { user }\end{array}$ & $\begin{array}{l}\text { Sesuai } \\
\text { harapan }\end{array}$ & Valid \\
\hline 3 & $\begin{array}{l}\text { Mengosongkan } \\
\text { selectbox hak akses } \\
\text { kemudian menekan } \\
\text { tombol simpan }\end{array}$ & $\begin{array}{l}\text { User: Aril } \\
\text { Tatum } \\
\text { Hak akses: } \\
\text { kosong }\end{array}$ & $\begin{array}{l}\text { Sistem menolak } \\
\text { dan } \\
\text { menampilkan } \\
\text { validasi pilih } \\
\text { hak akses }\end{array}$ & $\begin{array}{l}\text { Sesuai } \\
\text { harapan }\end{array}$ & Valid \\
\hline 4 & $\begin{array}{l}\text { Mengisi semua } \\
\text { selectbox kemudian } \\
\text { menekan tombol } \\
\text { simpan }\end{array}$ & $\begin{array}{l}\text { User: Aril } \\
\text { Tatum } \\
\text { Hak akses: } \\
\text { Administrasi }\end{array}$ & $\begin{array}{l}\text { Sistem } \\
\text { menerima dan } \\
\text { menyimpan } \\
\text { data user baru }\end{array}$ & $\begin{array}{l}\text { Sesuai } \\
\text { harapan }\end{array}$ & Valid \\
\hline
\end{tabular}

\section{Form Rekap Absensi}

Table 3

Hasil pengujian Black Box Testing Form Absensi

\begin{tabular}{|c|c|c|c|c|c|}
\hline No & Skenario Pengujian & Test Case & $\begin{array}{l}\text { Hasil yang } \\
\text { diharapkan }\end{array}$ & $\begin{array}{c}\text { Hasil } \\
\text { Pengujian }\end{array}$ & Kesimpulan \\
\hline 1 & $\begin{array}{l}\text { Mengosongkan } \\
\text { semua selectbox } \\
\text { kemudian menekan } \\
\text { tombol simpan }\end{array}$ & $\begin{array}{l}\text { Nama } \\
\text { karyawan: } \\
\text { kosong } \\
\text { Efektif: } \\
\text { kosong }\end{array}$ & \begin{tabular}{|l|} 
Sistem menolak \\
dan \\
menampilkan \\
pesan \\
Karyawan \\
belum dipilih \\
\end{tabular} & $\begin{array}{l}\text { Sesuai } \\
\text { harapan }\end{array}$ & Valid \\
\hline 2 & $\begin{array}{l}\text { Mengosongkan } \\
\text { selectbox nama } \\
\text { karyawan kemudian } \\
\text { menekan tombol } \\
\text { simpan }\end{array}$ & $\begin{array}{l}\text { Nama } \\
\text { karyawan: } \\
\text { kosong } \\
\text { Efektif: } 26\end{array}$ & \begin{tabular}{|l|} 
Sistem menolak \\
dan \\
menampilkan \\
pesan \\
Karyawan \\
belum dipilih \\
\end{tabular} & $\begin{array}{l}\text { Sesuai } \\
\text { harapan }\end{array}$ & Valid \\
\hline 3 & \begin{tabular}{|l} 
Mengosongkan \\
selectbox efektif \\
kerja kemudian \\
menekan tombol \\
simpan
\end{tabular} & $\begin{array}{l}\text { Nama } \\
\text { karyawan: } \\
\text { aril tatum } \\
\text { Efektif: } \\
\text { kosong }\end{array}$ & $\begin{array}{l}\text { Sistem menolak } \\
\text { dan } \\
\text { menampilkan } \\
\text { pesan Silahkan } \\
\text { tentukan hari } \\
\text { efektif kerja }\end{array}$ & $\begin{array}{l}\text { Sesuai } \\
\text { harapanan }\end{array}$ & Valid \\
\hline 3 & $\begin{array}{l}\text { Mengisi semua } \\
\text { selectbox kemudian } \\
\text { menekan tombol } \\
\text { simpan }\end{array}$ & $\begin{array}{l}\text { Nama } \\
\text { karyawan: } \\
\text { aril tatum } \\
\text { Efektif: } 26\end{array}$ & \begin{tabular}{|l} 
Sistem \\
menerima dan \\
menyimpan \\
data rekap \\
absen baru
\end{tabular} & $\begin{array}{l}\text { Sesuai } \\
\text { harapanan }\end{array}$ & Valid \\
\hline
\end{tabular}

\section{Kesimpulan}

Dari pembahasan yang telah diuraikan diatas dapat disimpulkan bahwa aplikasi slip gaji elektronik dibuat dengan tools editor Atom dan bahasa pemorgraman PHP yang dirancang dengan tampilan yang menarik dan sederhana, dengan adanya Implementasi slip gaji elektronik pada CV Mediaku Kreatif (Motion Production), diharapkan dapat memudahkan dalam pengolahan data penggajian, penyimpanan data dan backup data yang terstruktur serta terorganisir sehingga memudahkan dalam proses pencarian data yang dibutuhkan, dengan adanya slip gaji elektronik akan memudahkan karyawan untuk melihat slip gaji tanpa harus berada dikantor, karena karyawan dapat mengakses email dimanapun berada, penerapan slip gaji elektronik menghemat biaya karena slip gaji elektronik menggunakan sistem paperless. 


\section{Referensi}

Kadir, A. (2008). Belajar Database Menggunakan MySQL. Yogyakarta: Skripta Media Creative.

Kusrini. (2007). Konsep dan Aplikasi Sistem Penunjang Keputusan. Yogyakarta: Andi .

Mardi. (2011). Sistem Informasi Akuntansi. Bogor: Ghalia Indonesia.

Raharjo, B. (2011). Belajar Otodidak Membuat Database Menggunakan MySQL. Bandung: Informatika.

Rosa, A. S., \& Shalahuddin, M. (2015). Rekayasa Perangkat Lunak Terstruktur dan Berorientasi Objek. Bandung: Informatika.

Suyanto, \& Asep, H. (2009). Step by Step WEB DESIGN Theory and Practices. Yogyakarta: Andi.

Yaqub. (2008). Sistem Basis Data Tutorial Konseptual. Yogyakarta: Graha IImu. 